Ege Tıp Dergisi / Ege Journal of Medicine 2019;58(1):90-91

\title{
İzole hiperbilirubinemi ile başvuran akut apandisit olgusu
}

\author{
A case of acute appendicitis admitted with isolated hyperbilirubinemia

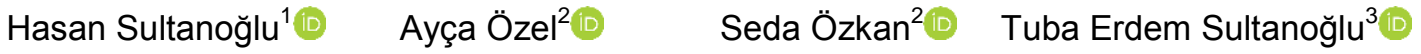 \\ ${ }^{1}$ Ersin Arslan Eğitim ve Araştırma Hastanesi, Acil Tıp Kliniği, Gaziantep, Türkiye \\ ${ }^{2}$ Dışkapı Yıldırım Beyazıt Eğitim ve Araştırma Hastanesi, Acil Tıp Kliniği, Ankara, Türkiye \\ ${ }^{3}$ Şehitkamil Devlet Hastanesi, Fiziksel Tıp ve Rehabilitasyon Kliniği, Gaziantep, Türkiye
}

\section{Öz}

Akut apandisit hastalarında, sarılık ve yaygın karın ağrısı nadir görülen bulgulardır. Çoğunlukla geç dönemde başvuran komplike ve perfore/gangrenöz apandisit ile ilişkilendirilir. Sarılığa neden olan hiperbilirübineminin yaygın nedenleri; genetik hastalıklar, enfeksiyonlar, karaciğer ve safra kesesi hastalıkları, toksinler ve kalp yetmezliğidir. Karaciğer enzim seviyesinin normal olduğu hiperbilirubinemi ise sepsis, sistemik enfeksiyon, metabolik hastalıklar ve gebelikte görülebilir. Bilirübin düzeyi acil serviste ulaşımı ve değerlendirilmesi kolay bir laboratuvar parametresidir. Acil servise akut sarılık ile başvuran hastalarda izole hiperbilirubinemi tespit edildiğinde akut apandisit ön tanısı da akılda tutulmalıdır.

Anahtar Sözcükler: Hiperbilirübinemi, karın ağrısı, perfore apandisit.

\begin{abstract}
Jaundice and diffuse abdominal pain are rare findings in patients with acute appendicitis and generally due to complicated late term of appendicitis such as perforated/gangrenous appendicitis. The common causes of hyperbilirubinemia which leads to jaundice are genetic disorders, infections, diseases of liver and gall bladder, toxins and heart failure. Hyperbilirubinemia with normal levels of liver enzymes could be the result of sepsis or systemic infections, metabolic disorders or pregnancy. Bilirubin levels could be easily detected in the emergency department. Acute appendicitis should be also kept in mind when isolated hyperbilirubinemia is detected in patients presenting with acute jaundice in the emergency department.
\end{abstract}

Keywords: Hyperbilirubinemia, abdominal pain, perforated appendicitis.

\section{Giriş}

Akut apandisit en sık rastlanan cerrahi akut karın tablosu olup tanı esas olarak anamnez ve fizik muayene bulgularıyla konulur. Akut apandisit hastalarında, sarılık ve yaygın karın ağrısı nadir görülen bulgulardır; çoğunlukla geç dönemde başvuran komplike ve perfore/gangrenöz apandisit ile ilişkilendirilir. Genetik hastalıklar, enfeksiyon, karaciğer ve safra yolu hastalıkları, toksinler, kalp yetmezliği sarılık kliniğine neden olabilir. Normal karaciğer enzim seviyelerinde görülen sarılık, primer hepatik hastalıktan çok sepsis, sistemik enfeksiyon, metabolizmanın doğuştan kusurları, hamilelik gibi nedenlerden kaynaklanabilir (1). Bu durum, portal venöz sistem ile karaciğere gelen aşırı bakteri ve toksin yükü sonucu, Kuppfer hücre fonksiyonunun artışı

\footnotetext{
Yazışma Adresi: Hasan Sultanoğlu

Ersin Arslan Eğitim ve Araştırma Hastanesi Acil Tıp Kliniği, Gaziantep, Türkiye

E-posta: drsultanoglu@hotmail.com

Makalenin Geliş Tarihi: 23.12.2017 Kabul Tarihi: 22.01.2018
}

ile beraber hepatosit hasarı ve ayrıca IL-6, TNF gibi akut faz reaktanlarının artışı sonucu karaciğer bilirübin yıkım fonksiyonlarının baskılanması ile beraber serum bilirübinlerinin artışına bağlanmaktadır (2,3-7). Bu olgu sunumunda karın ağrısı ve hiperbilirubinemisi olan hastalarda perfore/gangrenöz apandisitin akılda tutulması gerektiğini, anamnez ve fizik muayenenin önemini vurgulamak istedik.

\section{Olgu Sunumu}

On dokuz yaşında erkek hasta 3 gün önce başlayan karın ağrısı, ishal ve sarılık şikayetleri ile acil servise başvurdu. Hastanın anamnezinden 3 gün önce periumblikal bölgede başlayan karın ağrısının olduğu ve eşlik eden ishal şikayeti ile dış merkezde gastroenterit tanısı konularak tedavi edildiği öğrenildi. Karın ağrısının devam etmesi ve sarılık şikayetinin gelişmesi üzerine hasta dördüncü günde merkezimize başvurdu. Öz ve soy geçmişinde özellik yoktu. Fizik muayenesinde tüm ciltte ve sklerada ikterik görünüm, batında yaygın 
hassasiyet, periton irritasyon bulgusu mevcuttu. Vital bulguları normaldi. Laboratuvar değerlendirmesinde beyaz kan hücresi: $15600 / \mathrm{mm}^{3}$, total bilirübin: 6,61 $\mathrm{mg} / \mathrm{dL}$, direkt bilirübin: 0,55 mg/dL, AST: $21 \mathrm{U} / \mathrm{L}$, ALT: 7 $\mathrm{U} / \mathrm{L}, \mathrm{K}: 5,56 \mathrm{mEq} / \mathrm{L}, \mathrm{Na}: 133 \mathrm{mEq} / \mathrm{L}$ idi. Ultrasonografide (USG) sağ alt kadranda $8 \mathrm{~mm}$ çapında sonlanımı değerlen-dirilemeyen enflame appendiks ve komşuluğunda en derin yerin yerinde $3 \mathrm{~cm}$ serbest sıvı ile uyumlu görünüm izlendi. Hepatobiliyer USG'de patoloji saptanmadı. Hasta mevcut klinik, laboratuvar ve görüntüleme bulguları ile apandisit olarak değerlendirildi, genel cerrahi bölümüne konsülte edildi. Apandektomi uygulanan hasta perfore akut apandisit tanısını aldı. Postoperatif takibinde komplikasyon gelişmeyen hasta taburcu edildi.

Hastadan tıbbi verilerinin yayınlanabileceğine ilişkin yazılı onam belgesi alındı.

\section{Tartışma}

İzole hiperbilirübineminin sepsis ile ilişkisi literatürde net bir şekilde ortaya konmuştur (8). Son dönemlerde izole hiperbilirübinemi ve akut ya da perfore/gangrenöz apandisit ilişkisi üzerine çalışmalar yapılmıştır (2-7). Bilirübin seviyelerini komplike akut apandisit belirteci olarak değerlendiren çalışmalar da mevcuttur $(3,6)$. Ayrıca, bilirübin düzeyi acil serviste ulaşımı ve değerlendirilmesi kolay bir laboratuvar parametresidir. Acil servise akut sarılık ile başvuran hastalarda, izole hiperbilirübinemi saptanırsa anamnez ve fizik muayene derinleştirilmeli; akut batın, sepsis, masif hemoliz gibi gerçek tıbbi acil durumlar gözden kaçırılmamalıdır. Karın ağrısı ve sarılık şikayeti ile acil servise başvuran hastalarda perfore apandisit de akılda tutulması gereken tanılardan biridir.

\section{Kaynaklar}

1. O'Mara SR, Gebreyes K. Hepatic disorders. In: Tintinalli JE, Stapczynski JS, Ma OJ, Yealy DM, Meckler GD, Cline DM (eds). A Comprehensive Study Guide: Tintinalli's Emergency Medicine. $8^{\text {th }}$ ed. Mc Graw Hill; 2016:525.

2. Eren T, Tombak E, Ozemir IA, et al. Hyperbilirubinemia as a predictive factor in acute appendicitis. Eur J Trauma Emerg Surg 2015;00068(15):562-4.

3. Chaudhary P, Kumar A, Saxena N, Biswal UC. Hyperbilirubinemia as a predictor of gangrenous/perforated appendicitis: A prospective study. Ann Gastroenterol 2013;26(4):325-31.

4. Sevinç MM, Kınacı E, Çakar E, et al. Diagnostic value of basic laboratory parameters for simple and perforated acute appendicitis: An analysis of 3392 cases. Ulusal Travma Acil Cerrahi Dergisi 2016;22(2):155-62.

5. Estrada JJ, Petrosyan M, Barnhart J, et al. Hyperbilirubinemia in appendicitis: A New predictor of perforation. J Gastrointest Surg 2007;11(6):714-8.

6. Giordano S, Paakkönen M, Salminen P, Grönroos JM. Elevated serum bilirubin in assessing the likelihood of perforation in acute appendicitis: A diagnostic meta-analysis. Int J Surg 2013;11(9):795-800.

7. Khan S Kathmandu. Elevated serum bilirubin in acute appendicitis: A new diagnostic tool. Kathmandu Univ Med J 2008;6(2):161-5

8. Diagnostic Approach to the Adult with Jaundice or asymptomatic hyperbilirubinemia. [Updated Jan 29 2014; accessed Mar 2016]. Available from: URL: http://www.uptodate.com 